\title{
Structural basis of a ribozyme's thermostability: P1-L9 interdomain interaction in RNase P RNA
}

\author{
MICHAL MARSZALKOWSKI, DAGMAR K. WILLKOMM, and ROLAND K. HARTMANN \\ Institut für Pharmazeutische Chemie, Philipps-Universität Marburg, D-35037 Marburg, Germany
}

\begin{abstract}
For stability, many catalytic RNAs rely on long-range tertiary interactions, the precise role of each often being unclear. Here we demonstrate that one of the three interdomain architectural struts of RNase P RNA (P RNA) is the key to activity at higher temperatures: disrupting the P1-L9 helix-tetraloop interaction in P RNA of the thermophile Thermus thermophilus decreased activity at high temperatures in the RNA-alone reaction and at low $\mathrm{Mg}^{2+}$ concentrations in the holoenzyme reaction. Conversely, implanting the P1-P9 module of $T$. thermophilus in the P RNA from the mesophile Escherichia coli converted the latter RNA into a thermostable one. Moreover, replacing the $E$. coli P1-P9 elements with a pseudoknot module that mediates the homologous interaction in Mycoplasma P RNAs not only conferred thermostability upon $E$. coli P RNA but also increased its maximum turnover rate at $55^{\circ} \mathrm{C}$ to the highest yet described for a P RNA ribozyme.
\end{abstract}

Keywords: bacterial RNase P RNA; P1-L9 interdomain contact; thermostability

\section{INTRODUCTION}

The ribonucleoprotein enzyme RNase P catalyzes tRNA 5' end maturation in all organisms and organelles (Schön 1999). In bacteria, the RNA subunit (P RNA), $\sim 380$ nucleotides (nt) in size and encoded by the $r n p B$ gene, forms a specific complex with a single protein cofactor of $\sim 13 \mathrm{kDa}$. In vitro, bacterial P RNA has robust catalytic activity in the absence of the protein (Guerrier-Takada et al. 1983), but the latter is essential for function in vivo (Schedl et al. 1974; Gößringer et al. 2006). P RNAs from bacteria are subdivided into two distinct structural groups, termed type A (for "ancestral") and type B (for "Bacillus"; Hall and Brown 2001). P RNAs of both types consist of two independent folding domains, the specificity (S-) and the catalytic (C-) domains (Loria and Pan 1996, 1997), which are oriented toward each other by three interdomain loophelix contacts (Fig. 1A, L18-P8, L8-P4, P1-L9) in P RNAs of type $\mathrm{A}$ architecture. These long-range interactions, considered as architectural struts that stabilize the RNA's overall conformation, were originally identified by phylo-

Reprint requests to: Dagmar K. Willkomm, Institut für Pharmazeutische Chemie, Philipps-Universität Marburg, Marbacher Weg 6, D-35037 Marburg, Germany; e-mail: willkomm@staff.uni-marburg.de; or Roland K. Hartmann, Institut für Pharmazeutische Chemie, Philipps-Universität Marburg, Marbacher Weg 6, D-35037 Marburg, Germany; e-mail: roland.hartmann@staff.uni-marburg.de; fax +49-6421-2825854.

Article published online ahead of print. Article and publication date are at http://www.rnajournal.org/cgi/doi/10.1261/rna.762508. genetic covariation analyses (Brown et al. 1996; Massire et al. 1997, 1998) and later confirmed in the crystal structure of P RNA from Thermotoga maritima (Torres-Larios et al. 2005). The importance of the aforementioned as well as other (intradomain) long-range tertiary interactions for P RNA function were also demonstrated experimentally (e.g., Darr et al. 1992; Pomeranz Krummel and Altman 1999). However, the specific functional contributions of the L18-P8, L8-P4, and P1-L9 contacts are poorly understood.

We recently reported that $\mathrm{P}$ RNAs from thermophilic bacteria share a 5'-GYAA L9 tetraloop and a P1 receptor site consisting of a G-C base-pair (bp) tandem, a combination not present in other bacteria (Marszalkowski et al. 2006). Also, helices P1 and P9 are stabilized in P RNAs from thermophiles by helix extension and/or deletion of nucleotide bulges. These observations prompted us to scrutinize the importance of the P1-L9 interaction in $\mathrm{P}$ RNA of the thermophile Thermus thermophilus, an A-type $\mathrm{P}$ RNA with robust in vitro activity at temperatures of up to $75^{\circ} \mathrm{C}$ (Hartmann and Erdmann 1991) and to compare it to that of the mesophile Escherichia coli.

\section{RESULTS AND DISCUSSION}

\section{Activity of $T$. thermophilus P RNA with a disrupted P1-L9 interaction}

Initially, we disrupted the P1-L9 interaction in T. thermophilus P RNA by a sequence change of the L9 loop (Fig. 1B, 


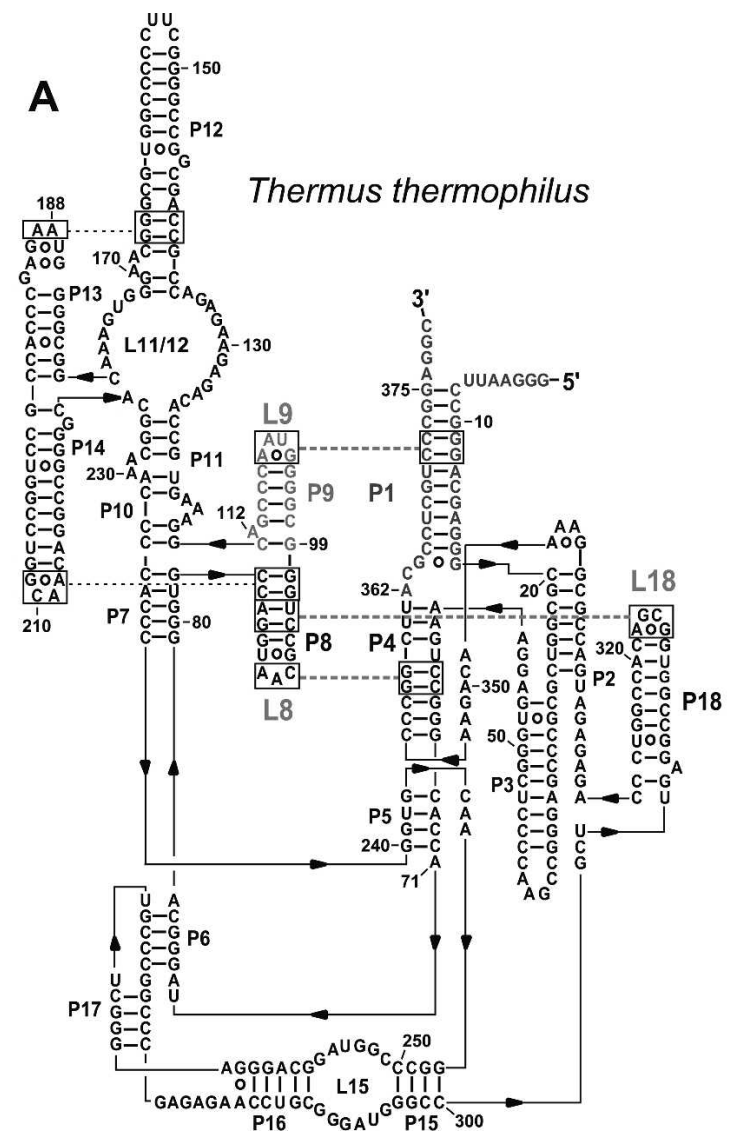

B

\section{T. thermophilus wt}

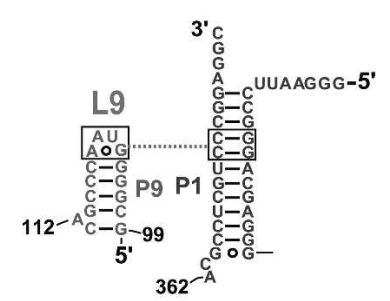

C
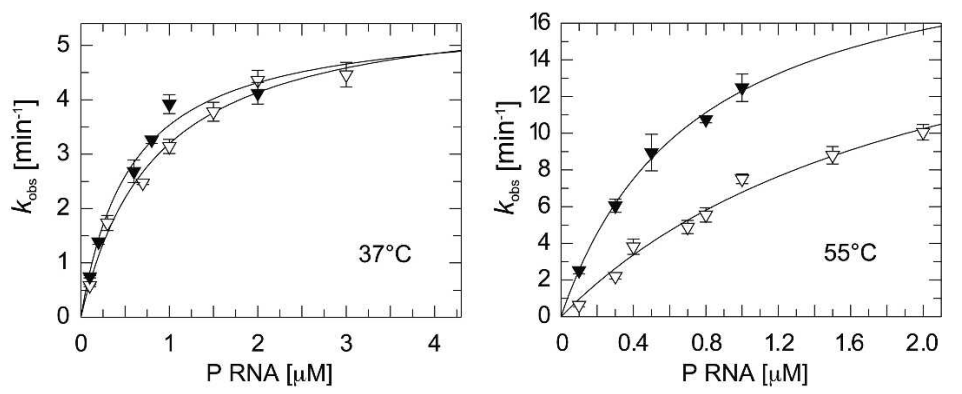

T. thermophilus wt

\section{T. thermophilus mL9}

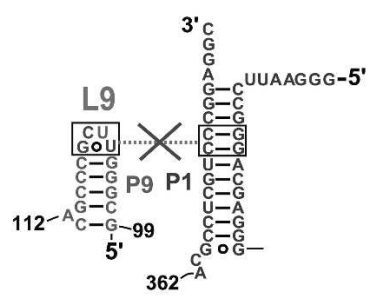

FIGURE 1. (A) Secondary structure presentation of T. thermophilus RNase P RNA according to Massire et al. (1998), with the three interdomain tetraloop-helix contacts L18-P8, L8-P4, and P1-L9 indicated by dashed lines. (B) P1-P9 region of the T. thermophilus wild-type P RNA (wt, left) and with the nucleotide exchanges in loop L9 that disrupt the P1-L9 interaction (mL9, right). (C) Processing assays with the two T. thermophilus P RNA variants. Assay conditions: $0.1-3 \mu \mathrm{M}$ P RNA, $<1 \mathrm{nM} 5^{\prime}$-end labeled ptRNA, $100 \mathrm{mM} \mathrm{Mg}(\mathrm{OAc})_{2}, 100 \mathrm{mM} \mathrm{NH}_{4} \mathrm{OAc}, 50 \mathrm{mM} \mathrm{MES}$, and $2 \mathrm{mM}$ EDTA $\left(\mathrm{pH} 6.0\right.$ ), and $37^{\circ} \mathrm{C}$ or $55^{\circ} \mathrm{C}$ as indicated. Error bars indicate standard deviations.

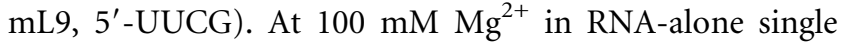
turnover reactions, the mutant showed a defect at $55^{\circ} \mathrm{C}$, but not at $37^{\circ} \mathrm{C}$ (Fig. 1C). This was caused mainly by a two- to threefold increase in $K_{\mathrm{m}(\mathrm{sto})}\left(K_{\mathrm{m}(\mathrm{sto})}\right.$, the single turnover $K_{\mathrm{m}}$, describes the enzyme concentration at which the half maximum rate under conditions of $[\mathrm{E}]>>[\mathrm{S}]$ is achieved) (Table 1). An even more pronounced defect (up to 24-fold decrease in cleavage rate) was seen in activity assays with reconstituted RNase $\mathrm{P}$ holoenzymes at $37^{\circ} \mathrm{C}$ and 2.0 or $4.5 \mathrm{mM} \mathrm{Mg}^{2+}$ (Table 2).

\section{Role of the P1-L9 interaction in folding of $T$. thermophilus P RNA}

Effects of the L9 mutation on P RNA folding were analyzed by native PAGE (Buck et al. 2005). While two main conformers were observed for $T$. thermophilus wild-type (wt) P RNA (Fig. 2A, bands 1,2), the L9 mutation indeed impeded formation of the faster migrating conformer 2, regardless of the presence or absence of $\mathrm{P}$ protein. To further characterize the two conformers of T. thermophilus wt P RNA, we eluted them separately from a native polyacrylamide gel at $4^{\circ} \mathrm{C}$ and reloaded aliquots of each eluate onto another native gel. Under these conditions, with the temperature not exceeding $15^{\circ} \mathrm{C}$ during elution and reelectrophoresis, both conformers did not reequilibrate to a substantial extent (Fig. 2B). In parallel, equal amounts of the two eluted conformers were tested in the holoenzyme reaction, performed at $22^{\circ} \mathrm{C}$ to mimize conformational reequilibration while maintaining high rates of substrate conversion. Approximately 15 -fold higher activity (data not shown) was observed with the eluted conformer 2 (Fig. 2B, lane b) relative to eluted conformer 1 (Fig. 2B, lane a).

The catalytic deficits of the L9 mutant RNA observed at low metal ion concentration in the holoenzyme reaction thus appear to be directly correlated to a folding defect. Accordingly, the L9-P1 interaction is crucial for folding into a conformation that either stabilizes the catalytic core of the enzyme and its metal ion binding sites or has increased affinity for the $\mathrm{P}$ protein and/or the substrate. 
TABLE 1. Summary of kinetic data of RNA-alone activity assays

\begin{tabular}{|c|c|c|c|c|}
\hline \multirow[b]{2}{*}{ RNase P RNA } & \multicolumn{2}{|c|}{$37^{\circ} \mathrm{C}$} & \multicolumn{2}{|c|}{$55^{\circ} \mathrm{C}$} \\
\hline & $K_{\mathrm{m}(\mathrm{sto})}(\mu \mathrm{M})$ & $k_{\text {react }}\left(\min ^{-1}\right)$ & $K_{\mathrm{m}(\mathrm{sto})}(\mu \mathrm{M})$ & $k_{\text {react }}\left(\min ^{-1}\right)$ \\
\hline T. thermophilus wt & $0.56 \pm 0.13$ & $5.5 \pm 0.5$ & $0.85 \pm 0.12$ & $22.7 \pm 1.8$ \\
\hline T. thermophilus $\mathrm{mL} 9$ & $0.83 \pm 0.12$ & $5.8 \pm 0.3$ & $2.1 \pm 0.5$ & $20.9 \pm 3.2$ \\
\hline E.coli wt & $0.65 \pm 0.02$ & $14.2 \pm 0.1$ & $1.3 \pm 0.2$ & $16.7 \pm 1.5$ \\
\hline E. coli $\mathrm{mL} 9$ & $0.33 \pm 0.08$ & $11.1 \pm 0.8$ & $0.9 \pm 0.2$ & $12.7 \pm 1.2$ \\
\hline E.coli P1P9 Tth & $0.44 \pm 0.09$ & $11.4 \pm 0.7$ & $0.6 \pm 0.1$ & $25.2 \pm 2.0$ \\
\hline E.coli P1P9 Mgen & $0.54 \pm 0.15$ & $10.9 \pm 1.1$ & $1.8 \pm 0.2$ & $35.1 \pm 1.9$ \\
\hline \multirow[t]{2}{*}{ E.coli P1P9 MgenA117C } & $0.30 \pm 0.08$ & $10.4 \pm 0.7$ & $3.3 \pm 0.7$ & $58.6 \pm 8.3$ \\
\hline & \multicolumn{2}{|c|}{$\begin{array}{l}\mathrm{k}_{\text {react }} / \mathrm{K}_{\mathrm{m}}\left[37^{\circ}\right] \\
\left(\mathrm{min}^{-1} \mu \mathrm{M}^{-1}\right)\end{array}$} & $\begin{array}{l}\mathrm{k}_{\text {react }} / \mathrm{K}_{\mathrm{m}}\left[5^{\circ}\right] \\
\left(\mathrm{min}^{-1} \mu \mathrm{M}^{-1}\right)\end{array}$ & $\begin{array}{l}\mathrm{K}_{\text {react }} / \mathrm{K}_{\mathrm{m}}\left[55^{\circ}:\right. \\
\mathrm{K}_{\text {react }} / \mathrm{K}_{\mathrm{m}}\left[3^{\circ}\right]\end{array}$ \\
\hline T. thermophilus wt & \multicolumn{2}{|c|}{9.82} & 26.71 & 2.72 \\
\hline T. thermophilus mL9 & \multicolumn{2}{|c|}{6.99} & 9.95 & 1.42 \\
\hline E. coli wt & \multicolumn{2}{|c|}{21.85} & 12.85 & 0.59 \\
\hline E. coli $\mathrm{mL} 9$ & \multicolumn{2}{|c|}{33.64} & 14.11 & 0.42 \\
\hline E. coli P1P9 Tth & \multicolumn{2}{|c|}{25.91} & 42.00 & 1.62 \\
\hline E. coli P1P9 Mgen & \multicolumn{2}{|c|}{20.19} & 19.50 & 0.97 \\
\hline E. coli P1P9 MgenA117C & \multicolumn{2}{|c|}{34.67} & 17.76 & 0.51 \\
\hline
\end{tabular}

(wt) Wild type, $\left(K_{\mathrm{m}(\mathrm{sto})}\right)$ single turnover $K_{\mathrm{m}}$ (describes the enzyme concentration at which the half maximum rate under conditions of [E] $>>[\mathrm{S}]$ is achieved), ( $k_{\text {react }}$ single turnover $\mathrm{V}_{\text {max }}$. All quantifications are based on at least three independent experiments; errors are standard errors of the curve fit; for reaction conditions see Materials and Methods.

\section{Role of the P1-L9 interaction in E. coli P RNA}

We then investigated the role of the $\mathrm{P} 1-\mathrm{L} 9$ interaction in P RNA from the mesophile E. coli (Fig. 3A) by disrupting the P1-L9 interaction (Fig. 3B, E. coli mL9, 5'-UCCG mutation) as done previously (Pomeranz Krummel and Altman 1999). However, this neither substantially impaired the RNA-alone reaction at $37^{\circ} \mathrm{C}$ (in accordance with Pomeranz Krummel and Altman 1999) or $55^{\circ} \mathrm{C}$ nor the holoenzyme reaction (Fig. 3C; Tables 1, 2), thus contrasting our results for T. thermophilus P RNA. The mutation was further neutral to viability (Table 3): The E. coli $\mathrm{L} 9$ mutant $r n p B$ gene provided on a low copy plasmid fully rescued growth of the E. coli P RNA mutant strain BW (Wegscheid and Hartmann 2006). Our data thus indicate that the P1-L9 interaction does not make a significant contribution to overall stabilization of E. coli P RNA. We like to note that an E. coli $\operatorname{rnpB}$ gene with the same L9 mutation failed to rescue the phenotype of $E$. coli strain NHY322 rnpA49, for which the temperature sensitivity of a mutant $\mathrm{P}$ protein at $43^{\circ} \mathrm{C}$ is compensated by $\mathrm{P}$ RNA overexpression (Pomeranz Krummel and Altman 1999). We do not know the reasons for this discrepancy, but the different nature of the test strains precludes a direct comparison.

\section{Introduction of $T$. thermophilus and Mycoplasma genitalium P1-P9 elements into $E$. coli P RNA}

We next replaced the P1-P9 elements of $E$. coli with those of T. thermophilus P RNA (Fig. 3B, E. coli P1P9 Tth).

TABLE 2. $k_{\mathrm{obs}}\left[\mathrm{min}^{-1}\right]$ in RNase P holoenzyme assays of $T$. thermophilus and $E$. coli wild-type (wt) and mutant P RNAs

\begin{tabular}{lcccc}
\hline & \multicolumn{2}{c}{ E. coli P protein } & \multicolumn{2}{c}{ B. subtilis P protein } \\
\cline { 2 - 4 } RNase P RNA & $2 \mathrm{mM} \mathrm{Mg}^{2+}$ & $4.5 \mathrm{mM} \mathrm{Mg}^{2+}$ & $2 \mathrm{mM} \mathrm{Mg}^{2+}$ & $1.1 \pm 0.1$ \\
\hline T. thermophilus wt & $1.3 \pm 0.2$ & $4.0 \pm 0.4$ & $0.28 \pm 0.03$ & $3.5 \pm 0.4$ \\
T. thermophilus mL9 & $0.054 \pm 0.008$ & $0.2 \pm 0.02$ & $3.0 \pm 0.3$ & $0.55 \pm 0.02$ \\
E.coli wt & $3.8 \pm 0.4$ & $3.8 \pm 0.4$ & $3.7 \pm 0.4$ & $4.0 \pm 0.3$ \\
E. coli $\mathrm{mL9}$ & $3.7 \pm 0.5$ & $4.2 \pm 0.4$ & & $4.1 \pm 0.4$ \\
E.coli P1P9 Mgen & $6.5 \pm 0.5$ & $8.4 \pm 1.0$ & \\
E.coli P1P9 MgenA117C & $3.2 \pm 0.3$ & $3.2 \pm 0.3$ & \\
\hline
\end{tabular}

Reactions were performed as multiple turnover kinetics with recombinant $\mathrm{P}$ protein at $37^{\circ} \mathrm{C}$ in a buffer containing $20 \mathrm{mM} \mathrm{HEPES}, 150 \mathrm{mM}$ $\mathrm{NH}_{4} \mathrm{OAc}, 2 \mathrm{mM}$ spermidine, $0.05 \mathrm{mM}$ spermine, $4 \mathrm{mM} \beta$-mercaptoethanol ( $\mathrm{pH} 7.4$ ) at $37^{\circ} \mathrm{C}$ and 2 or $4.5 \mathrm{mM} \mathrm{Mg}(\mathrm{OAc})_{2}$ as indicated, at concentrations of $10 \mathrm{nM}$ P RNA, $100 \mathrm{nM}$ substrate, and $40 \mathrm{nM}$ P protein; $k_{\text {obs }}$ is given as nanomoles substrate converted per nanomole of RNase P RNA per minute. For further details see Materials and Methods. 
A

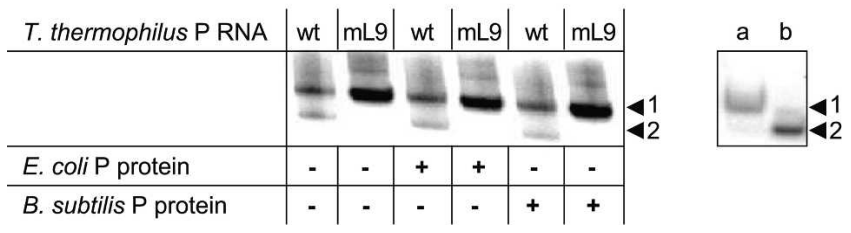

FIGURE 2. (A) Native PAGE analysis of T. thermophilus P RNA and its L9 mutant in the presence $(+)$ or absence $(-)$ of $\mathrm{P}$ protein. Trace amounts $(\leq 50 \mathrm{fmol})$ of $3^{\prime}$-end labeled P RNA were incubated in buffer $\mathrm{KN} 4.5$ for $5 \mathrm{~min}$ at $55^{\circ} \mathrm{C}$ followed by $50 \mathrm{~min}$ at $37^{\circ} \mathrm{C}$, and either with our without the addition of $40 \mathrm{nM}$ RNase P protein for another $15 \mathrm{~min}$ at $37^{\circ} \mathrm{C}$. Samples were loaded and run on $11.25 \%$ polyacrylamide gels in $1 \times$ THE buffer supplemented with $100 \mathrm{mM}$ $\mathrm{NH}_{4} \mathrm{OAc}$ and $4.5 \mathrm{mM} \mathrm{MgCl}$ (for further details, see Materials and Methods). (B) Stability of T. thermophilus wt P RNA conformers studied by reelectrophoresis after elution. T. thermophilus wt P RNA (10 nmol including 3 '-end labeled P RNA) was preincubated (see Materials and Methods) and then loaded on a native $11.25 \%$ polyacrylamide gel as in $A$. The two conformers (bands 1,2) were then eluted separately at $4^{\circ} \mathrm{C}$, and aliquots of each band were loaded onto another native $11.25 \%$ polyacrylamide gel. Electrophoreses were performed at $\leq 15^{\circ} \mathrm{C}$. Under these conditions, with the temperature not exceeding $15^{\circ} \mathrm{C}$ during elution and reelectrophoresis, both conformers did not reequilibrate to a substantial extent.

Compared to the E. coli wild type (wt), ribozyme activity of this hybrid P RNA at $37^{\circ} \mathrm{C}$ was also essentially unchanged, but relatively increased to a substantial extent at $55^{\circ} \mathrm{C}$ (Fig. 3C; Table 1). Again the mutant P RNA was functional in vivo (Table 3). Finally, an exceptional kind of P1-P9 interaction exists in some P RNAs of the genus Mycoplasma, which possess a P RNA of type B and where P9 and P1 juxtapose via a pseudoknot instead of the tetraloophelix contact apparent in many type A P RNAs (Massire et al. 1997). Built into E. coli P RNA as an interaction module expected to be of particularly high stability (Fig. 3B, E. coli P1P9 Mgen), the pseudoknot of M. genitalium had little effect on the RNA-alone reaction at $37^{\circ} \mathrm{C}$ but substantially increased the cleavage rate at $55^{\circ} \mathrm{C}$ (Fig. $3 \mathrm{C}$ ), the maximum cleavage rate obtained with this variant even exceeding that of E. coli $\mathrm{P} 1 \mathrm{P} 9$ Tth (Table 1). In the holoenzyme reaction, cleavage rates were roughly twice that of $E$. coli wt P RNA (Table 2), and again, the hybrid P RNA was fully functional in vivo (Table 3). Finally, we intended to stabilize the interacting module even further by an A117 to C mutation in Mgen P9 to introduce an additional Watson-Crick base pair (Fig. 3B). This mutation generated a variant with the highest maximum turnover rate at $55^{\circ} \mathrm{C}$ yet described for a P RNA ribozyme (Table 1).

The fast substrate turnover catalyzed by the chimeric RNAs E. coli P1P9 Mgen and MgenA117C in the RNA-alone reaction at $55^{\circ} \mathrm{C}$ was associated with an increase in the single turnover $K_{\mathrm{m} \text { (sto) }}$ compared with cleavage at $37^{\circ} \mathrm{C}$, in particular for variant E. coli P1P9 MgenA117C (Table 1). This effect may be due to a loss in substrate binding affinity or to a reduction in the fraction of $\mathrm{P}$ RNAs that are competent to bind the substrate at $55^{\circ} \mathrm{C}$. While this $K_{\mathrm{m}}$ effect may have various reasons, the stronger $K_{\mathrm{m}}$ effect for variant E. coli P1P9 MgenA117C (Fig. 3B) may be explained by the mutant C117-G108 bp constraining the orientation of A118, such that stacking of A118 on another bulged A residue in P11 (A233) (Fig. 3A; Lescoute and Westhof 2006) is weakened and becomes unstable at the higher temperature of $55^{\circ} \mathrm{C}$.

\section{CONCLUSIONS}

From the presented data we conclude that the P1-L9 tertiary contact is crucial for folding and activity of $\mathrm{P}$ RNA from the thermophile T. thermophilus at high temperatures and low magnesium ion concentrations, conditions that require high intrinsic stability of the RNA. Our native PAGE analysis suggests that this interacting module represents one of the key anchoring points toward folding into the most active RNA conformer. These results extend present knowledge on the thermostability of P RNA from T. thermophilus: While Pan and coworkers identified 12 key base identities in the T. thermophilus S-domain that explain its stability increase over the corresponding $E$. coli domain (Baird et al. 2006), we were able to pinpoint an interdomain strut crucial for function of the entire RNA.

In contrast, the P1-L9 interaction appears degenerate in E. coli-like mesophilic P RNAs and could be completely disrupted without compromising function in vitro as well as in vivo. Yet, though not made use of in E. coli, in this $\mathrm{P}$ RNA the location of the P1-L9 interaction module has nonetheless remained a key position for placing an architecturally highly effective interdomain strut: If building in a strongly interacting P1-L9 module, E. coli P RNA gains substantially in activity at high temperatures. The architectural framework governing P RNA overall statics has thus been preserved between the thermophilic and mesophilic P RNA.

Finally, our findings identify the P1-L9 receptor/ tetraloop of $T$. thermophilus and the corresponding pseudoknot from M. genitalium as (thermo)stabilization modules for complex RNAs that comply with the concept of modular "plug and play" interchangeability (Costa and Michel 1995, 1997; Qin et al. 2001). They may thus expand the spectrum of modules that can be exploited to stabilize larger RNAs for structural analysis (Ferré-D’Amaré et al. 1998).

\section{MATERIALS AND METHODS}

\section{Cloning of transcription templates and complementation plasmids}

All plasmids were constructed by standard PCR and cloning techniques. 


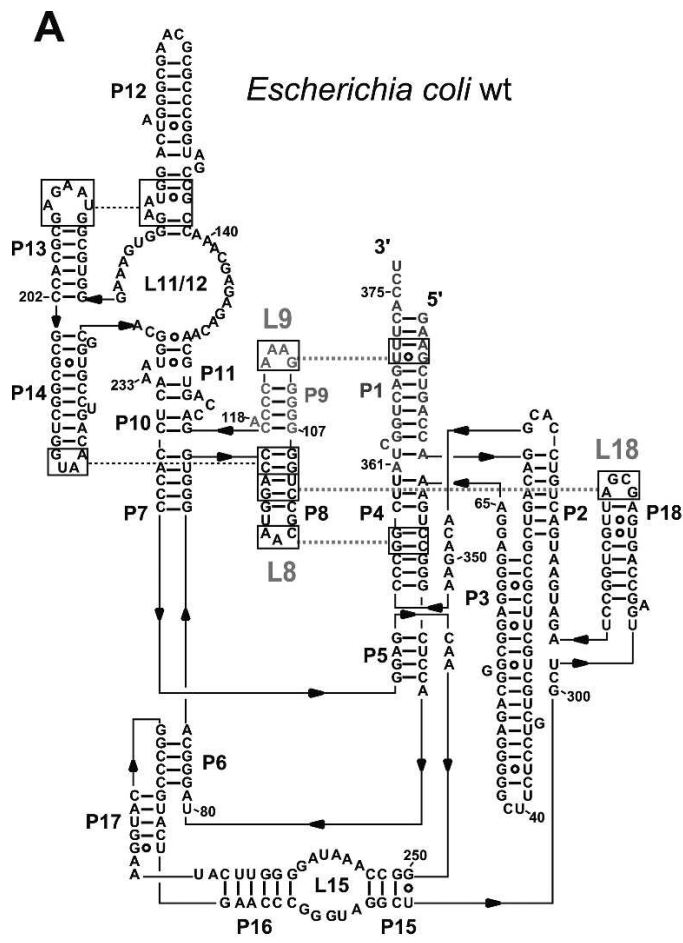

B
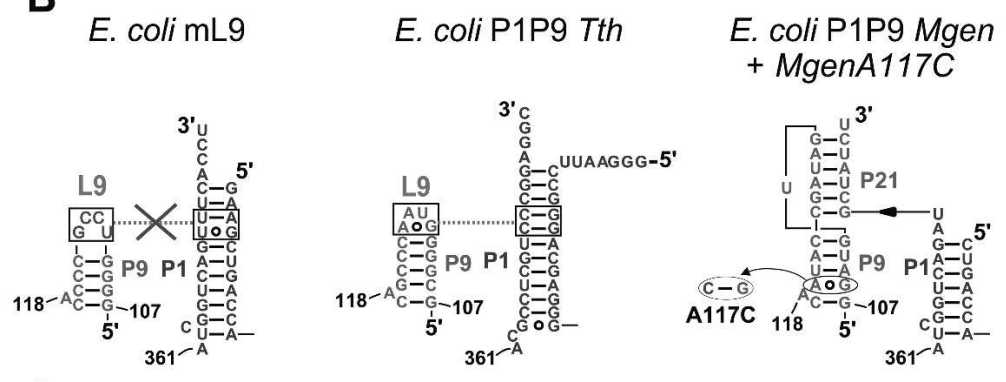

C
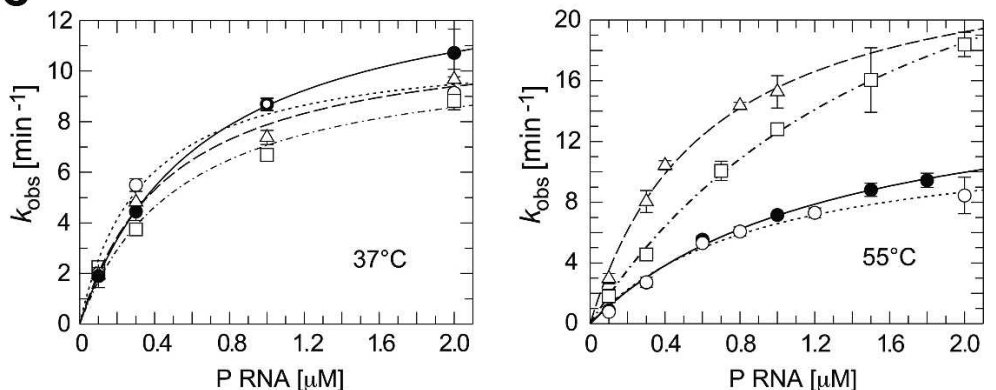

\begin{tabular}{|ll|}
\hline- E. coli wt & $-\triangle-$ E. coli P1P9 Tth \\
- - E. coli $\mathrm{mL9}$ & $-\square-$ E. coli P1P9 Mgen
\end{tabular}

FIGURE 3. Secondary structure presentation of $(A)$ E. coli wild-type (wt) P RNA and $(B)$ alterations in the P1-P9 mutants thereof. mL9: Nucleotide changes in loop L9 that disrupt the P1-L9 interaction; P1P9 Tth: E. coli P1P9 replaced with the corresponding elements of T. thermophilus P RNA; P1P9 Mgen: E. coli P1P9 replaced with the pseudoknot from M. genitalium; P1P9 MgenA117C: variant of P1P9 Mgen, with a single nucleotide (A117C) exchanged. (C) Processing assays with the E. coli P RNA variants performed as described in the legend to Figure 1C.

\section{Preparation and labeling of substrate and P RNA}

ptRNA substrate and P RNAs were obtained by run-off transcription with recombinant bacteriophage T7 RNA polymerase and were $5^{\prime}$ - and $3^{\prime}$-end labeling essentially as described (Heide et al. 1999; Busch et al. 2000). The T. thermophilus ptRNA Gly substrate was transcribed from plasmid pSBpt3'HH linearized with BamHI (Busch et al. 2000); E. coli wild-type P RNA was transcribed from plasmid pJA2' linearized with FokI (Vioque et al. 1988; Busch et al. 2000), T. thermophilus P RNA variants from plasmid pUC19TthrnpBwt and pUC19TthrnpBmL9 linearized with EheI; all E. coli mutant P RNAs were transcribed from respective pUC19-derivatives linearized with EcoRI (E. coli mL9, E. coli P1P9 Tth, E. coli P1P9 Mgen, and E. coli P1P9 MgenA117C). The gift of pUC19TthrnpBwt from Andreas Werner, group of Eric Westhof, IBMC Strasbourg, is gratefully acknowledged.

\section{RNase P RNA and holoenzyme activity assays}

RNase P RNA-alone activity assays were performed in $100 \mathrm{mM}$ $\mathrm{Mg}(\mathrm{OAc})_{2}, 100 \mathrm{mM} \mathrm{NH}_{4} \mathrm{OAc}, 50 \mathrm{mM} \mathrm{MES}$, and $2 \mathrm{mM}$ EDTA ( $\mathrm{pH}$ 6.0), with trace amounts of $5^{\prime}$-end labeled substrate and $\mathrm{P}$ RNA concentrations in the range of $0.1-3 \mu \mathrm{M}$. Before starting the reaction, substrate and P RNA were preincubated separately in the assay buffer (ptRNA ${ }^{\text {Gly }}$ substrate for $5 \mathrm{~min}$ at $55^{\circ} \mathrm{C}$ and $20 \mathrm{~min}$ at $37^{\circ} \mathrm{C}, \mathrm{P}$ RNAs for $5 \mathrm{~min}$ at $55^{\circ} \mathrm{C}$ and $55 \mathrm{~min}$ at $37^{\circ} \mathrm{C}$ ). Reactions were run for $5-30 \mathrm{~min}$ at $37^{\circ} \mathrm{C}$ or $55^{\circ} \mathrm{C}$ as indicated.
Activity of RNase $\mathrm{P}$ holoenzymes was measured in buffer $\mathrm{KN}$ (20 mM HEPES, $150 \mathrm{mM} \mathrm{NH}_{4} \mathrm{OAc}, 2 \mathrm{mM}$ spermidine, $0.05 \mathrm{mM}$ spermine, $4 \mathrm{mM} \beta$-mercaptoethanol at $\mathrm{pH} 7.4$ at $37^{\circ} \mathrm{C}$ ) containing 2 or $4.5 \mathrm{mM} \mathrm{Mg}(\mathrm{OAc})_{2}$ (buffer $\mathrm{KN} 2$ and $\mathrm{KN} 4.5$; Wegscheid and Hartmann 2006), at concentrations of $10 \mathrm{nM}$ P RNA, $100 \mathrm{nM}$ substrate, and $40 \mathrm{nM}$ P protein (recombinantly expressed and purified exactly as in Marszalkowski et al. 2006). Prior to the reaction, substrate and P RNA were preincubated in the reaction buffer (substrate as above, P RNA for $5 \mathrm{~min}$ at $55^{\circ} \mathrm{C}$ and $50 \mathrm{~min}$ at $37^{\circ} \mathrm{C}$ ); $\mathrm{P}$ protein was then added to the $\mathrm{P}$ RNA and preincubation continued for another $5 \mathrm{~min}$ at $37^{\circ} \mathrm{C}$, after which substrate was added. Analysis of cleavage reactions and data evaluation were carried out as described (Busch et al. 2000).

\section{Folding analysis by native PAGE}

Folding analyses were performed essentially as described (Wegscheid and Hartmann 2006). In Figure 2A, trace amounts ( $\leq 50 \mathrm{fmol}$ ) of $3^{\prime}$-end labeled P RNA were incubated in buffer KN4.5 (see above) for $5 \mathrm{~min}$ at $55^{\circ} \mathrm{C}$ followed by $50 \mathrm{~min}$ at $37^{\circ} \mathrm{C}$ and either with or without the addition of $40 \mathrm{nM}$ RNase $\mathrm{P}$ protein for another $15 \mathrm{~min}$ at $37^{\circ} \mathrm{C}$. After addition of an equal volume of loading buffer $(10 \%$ [v/v] glycerol, $4.5 \mathrm{mM} \mathrm{MgCl}$, $0.025 \%[\mathrm{w} / \mathrm{v}]$ each bromophenol blue and xylene cyanol), samples were run on an $11.25 \%(\mathrm{v} / \mathrm{v})$ polyacrylamide gel containing $66 \mathrm{mM}$ HEPES, $33 \mathrm{mM}$ Tris, $0.1 \mathrm{mM}$ EDTA, $100 \mathrm{mM}$ $\mathrm{NH}_{4} \mathrm{OAc}$, and $4.5 \mathrm{mM} \mathrm{Mg}(\mathrm{OAc})_{2}$ (pH 7.4) (buffer system 
TABLE 3. In vivo complementation screen in E. coli rnpB mutant strain BW

\begin{tabular}{lcc}
\hline & \multicolumn{2}{c}{ Complementation } \\
\cline { 2 - 3 } rnpB & $37^{\circ}$ & $43^{\circ}$ \\
\hline None & - & - \\
E. coli wt & ++ & ++ \\
E. coli C293 or C292 & - & - \\
E. coli $\mathrm{mL9}$ & ++ & ++ \\
E. coli P1P9 Tth & ++ & ++ \\
E. coli P1P9 Mgen & ++ & ++ \\
E. coli P1P9 MgenA117C & + & ++ \\
T. thermophilus wt & - & - \\
$T$. thermophilus $\mathrm{mL9}$ & n.d. & n.d. \\
\hline
\end{tabular}

Growth of cells was monitored in the presence of $0.5 \%(\mathrm{w} / \mathrm{v})$ glucose (without arabinose), conditions under which the chromosomal $r n p B$ gene of the E. coli mutant strain BW is not expressed (at $37^{\circ}$ as well as $43^{\circ} \mathrm{C}$ ); cells were transformed with derivatives of the low copy plasmid pACYC177 that contained $r n p B$ genes coding for $\mathrm{P}$ RNAs and mutants thereof under control of the native $r n p B$ promoter. E. coli rnpB genes with G293C or G292C point mutations were previously shown to be lethal (Wegscheid and Hartmann 2006); (-) No cell growth; $(++)$ growth with equal numbers of colonies on arabinose and glucose plates; (+) somewhat decreased complementation efficiency according to number and size of colonies; (n.d.) not determined because the $T$. thermophilus wild-type (wt) $r n p B$ gene already does not complement, likely because of folding traps (data not shown) at the growth temperatures of the E. coli strain.

adapted from Buck et al. 2005), with the gel temperature not exceeding $15^{\circ} \mathrm{C}$. RNA bands were visualized with a Bio-Imaging Analyzer (FLA 3000-2R, Fujifilm). For reelectrophoresis and activity testing of $T$. thermophilus wt P RNA conformers (Fig. 2B), $20 \mathrm{nM}$ of unlabeled P RNA plus $20 \times 10^{3}$ Cerenkov cpm of $3^{\prime}$-end labeled P RNA per gel lane were preincubated in buffer $\mathrm{KN} 4.5$ for $10 \mathrm{~min}$ at $55^{\circ} \mathrm{C}$ in a volume of $7 \mu \mathrm{L}$; after addition of $7 \mu \mathrm{L}$ loading buffer (see above), samples were subjected to native PAGE as described above. After electrophoresis and $1 \mathrm{~h}$ of phosphorimager plate exposition, the two conformers were excised separately from the gel and eluted in $50 \mu \mathrm{L}$ of buffer KN4.5 (see above) without $\mathrm{Mg}^{2+}$ by shaking overnight at $4^{\circ} \mathrm{C}$. To analyze stability of the conformers, eluted material from each band was subsequently supplemented with loading buffer and run on a second native polyacrylamide gel (Fig. 2B). To compare the conformers for differences in catalytic activity, $\sim 3.5 \mathrm{nM}$ of each eluted conformer were used in holoenzyme cleavage assays performed under multiple turnover conditions (reaction buffer KN4.5, $100 \mathrm{nM}$ ptRNA, $40 \mathrm{nM}$ B. subtilis RNase $\mathrm{P}$ protein). Assays were carried out at $22^{\circ} \mathrm{C}$ without any preincubation steps to eliminate potential heat-induced conformational changes.

\section{In vivo complementation assays in $E$. coli strain BW}

In vivo complementation assays were performed in the $E$. coli $r n p B$ mutant strain $\mathrm{BW}$ with derivatives of the low copy plasmid pACYC177 precisely as described (Wegscheid and Hartmann 2006).

\section{ACKNOWLEDGMENTS}

This work was supported by the Deutsche Forschungsgemeinschaft and the Fonds der Chemischen Industrie.

Received August 2, 2007; accepted September 10, 2007.

\section{REFERENCES}

Baird, N.J., Srividya, N., Krasilnikov, A.S., Mondragon, A., Sosnick, T.R., and Pan, T. 2006. Structural basis for altering the stability of homologous RNAs from a mesophilic and a thermophilic bacterium. RNA 12: 598-606.

Brown, J.W., Nolan, J.M., Haas, E.S., Rubio, M.A., Major, F., and Pace, N.R. 1996. Comparative analysis of ribonuclease $P$ RNA using gene sequences from natural microbial populations reveals tertiary structural elements. Proc. Natl. Acad. Sci. 93: 3001-3006.

Buck, A.H., Dalby, A.B., Poole, A.W., Kazantsev, A.V., and Pace, N.R. 2005. Protein activation of a ribozyme: The role of bacterial RNase P protein. EMBO J. 24: 3360-3368.

Busch, S., Kirsebom, L.A., Notbohm, H., and Hartmann, R.K. 2000. Differential role of the intermolecular base-pairs G292-C75 and G293-C74 in the reaction catalyzed by Escherichia coli RNase P RNA. J. Mol. Biol. 299: 941-951.

Costa, M. and Michel, F. 1995. Frequent use of the same tertiary motif by self-folding RNAs. EMBO J. 14: 1276-1285.

Costa, M. and Michel, F. 1997. Rules for RNA recognition of GNRA tetraloops deduced by in vitro selection: Comparison with in vivo evolution. EMBO J. 16: 3289-3302.

Darr, S.C., Zito, K., Smith, D., and Pace, N.R. 1992. Contributions of phylogenetically variable structural elements to the function of the ribozyme ribonuclease P. Biochemistry 31: 328-333.

Ferré-D'Amaré, A.R., Zhou, K., and Doudna, J.A. 1998. A general module for RNA crystallization. J. Mol. Biol. 279: 621-631.

Gößringer, M., Kretschmer-Kazemi Far, R., and Hartmann, R.K. 2006. Analysis of RNase P protein ( $r p p A)$ expression in Bacillus subtilis utilizing strains with suppressible rnpA expression. J. Bacteriol. 188: 6816-6823.

Guerrier-Takada, C., Gardiner, K., Marsh, T., Pace, N., and Altman, S. 1983. The RNA moiety of ribonuclease $\mathrm{P}$ is the catalytic subunit of the enzyme. Cell 35: 849-857.

Hall, T.A. and Brown, J.W. 2001. The ribonuclease P family. Methods Enzymol. 341: 56-77.

Hartmann, R.K. and Erdmann, V.A. 1991. Analysis of the gene encoding the RNA subunit of ribonuclease $\mathrm{P}$ from T. thermophilus HB8. Nucleic Acids Res. 19: 5957-5964. doi: 10.1093/nar/ 19.21.5957.

Heide, C., Pfeiffer, T., Nolan, J.M., and Hartmann, R.K. 1999. Guanosine 2- $\mathrm{NH}_{2}$ groups of Escherichia coli RNase P RNA involved in intramolecular tertiary contacts and direct interactions with tRNA. RNA 5: 102-116.

Lescoute, A. and Westhof, E. 2006. The interaction networks of structured RNAs. Nucleic Acids Res. 34: 6587-6604. doi: 10.1093/ nar/gkl963.

Loria, A. and Pan, T. 1996. Domain structure of the ribozyme from eubacterial ribonuclease P. RNA 2: 551-563.

Loria, A. and Pan, T. 1997. Recognition of the T stem-loop of a pretRNA substrate by the ribozyme from Bacillus subtilis ribonuclease P. Biochemistry 36: 6317-6325.

Marszalkowski, M., Teune, J.H., Steger, G., Hartmann, R.K., and Willkomm, D.K. 2006. Thermostable RNase P RNAs lacking P18 identified in the Aquificales. RNA 12: 1915-1921.

Massire, C., Jaeger, L., and Westhof, E. 1997. Phylogenetic evidence for a new tertiary interaction in bacterial RNase P RNAs. RNA 3: 553-556.

Massire, C., Jaeger, L., and Westhof, E. 1998. Derivation of the three-dimensional architecture of bacterial ribonuclease 
P RNAs from comparative sequence analysis. J. Mol. Biol. 279: 773-793.

Pomeranz Krummel, D.A. and Altman, S. 1999. Verification of phylogenetic predictions in vivo and the importance of the tetraloop motif in a catalytic RNA. Proc. Natl. Acad. Sci. 96: 11200-11205.

Qin, H., Sosnick, T.R., and Pan, T. 2001. Modular construction of a tertiary RNA structure: The specificity domain of the Bacillus subtilis RNase P RNA. Biochemistry 40: 11202-11210.

Schedl, P., Primakoff, P., and Roberts, J. 1974. Processing of E. coli tRNA precursors. Brookhaven Symp. Biol. 26: 53-76.
Schön, A. 1999. Ribonuclease P: The diversity of a ubiquitous RNA processing enzyme. FEMS Microbiol. Rev. 23: 391-406.

Torres-Larios, A., Swinger, K.K., Krasilnikov, A.S., Pan, T., and Mondragon, A. 2005. Crystal structure of the RNA component of bacterial ribonuclease P. Nature 437: 584-587.

Vioque, A., Arnez, J., and Altman, S. 1988. Protein-RNA interactions in the RNase P holoenzyme from Escherichia coli. J. Mol. Biol. 202: 835-848.

Wegscheid, B. and Hartmann, R.K. 2006. The precursor tRNA 3'CCA interaction with Escherichia coli RNase P RNA is essential for catalysis by RNase $\mathrm{P}$ in vivo. RNA 12: 2135-2148. 

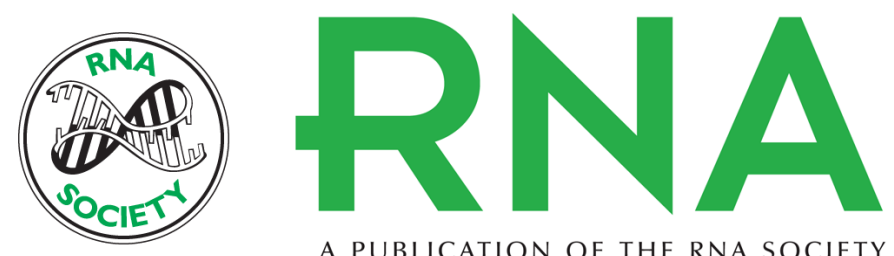

A PUBLICATION OF THE RNA SOCIETY

\section{Structural basis of a ribozyme's thermostability: P1-L9 interdomain interaction in RNase P RNA}

Michal Marszalkowski, Dagmar K. Willkomm and Roland K. Hartmann

RNA 2008 14: 127-133

References This article cites 26 articles, 10 of which can be accessed free at:

http://rnajournal.cshlp.org/content/14/1/127.full.html\#ref-list-1

License

Email Alerting Receive free email alerts when new articles cite this article - sign up in the box at the Service top right corner of the article or click here. 